Article

\title{
Organic Dyes in Dye-Sensitized Solar Cells Featuring Back Reflector
}

\author{
Agata Zdyb *(D) and Ewelina Krawczak (D) \\ Department of Renewable Energy Engineering, Faculty of Environmental Engineering, \\ Lublin University of Technology, Nadbystrzycka 40B, 20-618 Lublin, Poland; e.krawczak@pollub.pl \\ * Correspondence: a.zdyb@pollub.pl; Tel.: +48-81-5384747
}

Citation: Zdyb, A.; Krawczak, E. Organic Dyes in Dye-Sensitized Solar Cells Featuring Back Reflector. Energies 2021, 14, 5529. https:// doi.org/10.3390/en14175529

Academic Editors: Adalgisa Sinicropi and Bashir A. Arima

Received: 2 July 2021

Accepted: 30 August 2021

Published: 4 September 2021

Publisher's Note: MDPI stays neutral with regard to jurisdictional claims in published maps and institutional affiliations.

Copyright: (c) 2021 by the authors. Licensee MDPI, Basel, Switzerland. This article is an open access article distributed under the terms and conditions of the Creative Commons Attribution (CC BY) license (https:// creativecommons.org/licenses/by/ $4.0 /)$.

\begin{abstract}
Dye-sensitized solar cells (DSSCs) were fabricated using a photoelectrode covered by a porous layer of titanium dioxide, platinum counter electrode, iodide/triiodide electrolyte and three different dyes: phenylfluorone (PF), pyrocatechol violet (PCV) and alizarin (AL). After the adsorption of the dyes on the mesoporous $\mathrm{TiO}_{2}$ layer, the measurement of absorption spectra of all the tested dyes revealed a significant broadening of the absorption range. The positions of highest occupied molecular orbital (HOMO) and lowest occupied molecular orbital (LUMO) levels of dye molecules were determined, indicating that all three dyes are good candidates for light harvesters in DSSCs. The cells were tested under simulated solar light, and their working parameters were determined. The results showed that the implementation of the back reflector layer made of $\mathrm{BaSO}_{4}$ provided an improvement in the cell efficiency of up to $17.9 \%$ for phenylfluorone, $60 \%$ for pyrocatechol violet and $21.4 \%$ for alizarin dye.
\end{abstract}

Keywords: dye-sensitized solar cell; DSSC; organic dye; back reflector; light trapping; enediol group

\section{Introduction}

The usage of solar energy for production of electricity implies a constant increase in investment in the investigations of photovoltaic (PV) technology. Despite the strong position of silicon solar cells in the market, much attention is attracted by the emerging photovoltaic technologies such as organic photovoltaics (OPV) and dye-sensitized solar cells (DSSCs), as well as perovskite cells (PSCs) that stemmed from DSSCs. Dye-sensitized photovoltaic devices are well known for low-cost production, beneficial energy payback time, easy recycling and simple structure. A dye cell is essentially composed of an anode covered by titanium dioxide nanoparticles with adsorbed photoactive dye molecules, counter electrode and electrolyte inserted in between [1]. The illumination of the photoanode is followed by the excitation of a dye molecule and the injection of the excited electron into the conduction band of titanium dioxide. The electrons can travel through the mesoporous layer consisting of $\mathrm{TiO}_{2}$ nanoparticles and then by the external circuit to the counter electrode. Here, the electrons reduce the electrolyte, which in turn regenerates the oxidized dye molecules. In the whole operation cycle, the crucial process is the electron transfer from the dye molecule to the $\mathrm{TiO}_{2}$ conduction band [2,3]. The mechanism of this process depends on the configuration and electronic structure of the adsorbed dyes [4]. The dye is the core component of a DSSC that sensitizes $\mathrm{TiO}_{2}$ by broadening the spectrum of absorbed light from UV to NIR since the $\mathrm{TiO}_{2}$ absorbs only UV light. In order to enhance the light harvesting, it is desirable that the absorption spectrum of the dye adsorbed on $\mathrm{TiO}_{2}$ covers a broad spectral range. The highest occupied molecular orbital (HOMO) energy level of the dye molecule should be lower than the redox potential of the electrolyte, while the lowest unoccupied molecular orbital (LUMO) should be located higher than the edge of the semiconductor conduction band.

Good DSSC performance, confirmed by the efficiency of over 10\% [1], was exhibited by the cells sensitized with ruthenium complexes (e.g., N3, N719 dyes); however, their 
application is limited due to the scarcity of rare transition elements, high cost of these compounds and environmental hazard.

Another group of sensitizers, characterized by tunable optical, photophysical and electrochemical properties, are porphyrins, which contain an inexpensive metal and are constructed in $\mathrm{D}-\pi-\mathrm{A}$ (donor- $\pi$-conjugated linker-acceptor) configuration, aiming for efficient intramolecular charge transfer and broad light absorption. The investigations of porphyrin dyes, both theoretical and experimental [5-8], resulted in an efficiency of 13\% with cobalt (II/III) redox shuttle [9].

Many different metal-free sensitizers that have unique advantages (broad absorption, low cost, simple synthesis) were also implemented in DSSCs and serve as an effective alternative to ruthenium complexes. Among them, the triphenylamine dyes, the structure of which ensures broad photon harvesting range and prevents unfavorable dye aggregation, led to the DSSC power conversion efficiency (PCE) of about 3.5\% [10]. Other metal-free compounds applied in dye cells include coumarin dyes (providing PCE 6.07\% [11] or $4.78 \%$ [12]), carbazole dyes (PCE 3.55\% [13] or 2.2\% [14]), indole dyes or their derivatives for cosensitization (PCE 9.56\% [15]), cyanine dyes (PCE 0.24\% [16]) or recently blue dye R6 (PCE 12.6\% [17]). The record efficiency of over 14\% was delivered by dye cells cosensitized with alkoxysilyl-anchor dye ADEKA-1 and a carboxy-anchor organic dye LEG4 in which cobalt-based electrolyte was used [18].

In recent years, natural dyes such as flavonoids, betalains, tannins, chlorophylls and carotenoids extracted from plants have also been successfully used as light harvesters in DSSCs [19-22]. Their advantages over synthetic dyes include cost-effectiveness, nontoxicity and possible biodegradation.

This work focuses on three organic metal-free dyes (see Figure 1), namely phenylfluorone (PF), pyrocatechol violet (PCV) and alizarin (AL), and their application in dye cells as photosensitizers. Phenylfluorone (9-phenyl-3-fluorone, fluorone black) consists of fluorine with a phenyl group (Figure 1). Phenylfluorone and its derivatives are widely used as analytical agents in spectrophotometry and fluorescent spectrometry for the detection of metal ions [23]. Pyrocatechol violet is a sulfone phthalein dye, which is one of the organic reagents recommended for the studies of complexation as a ligand with metal ions such as indium and gallium toward the applications in nuclear medicine as well as in metal extraction and determination studies [24]. Alizarin (dihydroxyanthraquinone) is extracted from plant roots but can also be synthesized, and it is usually used as a textile red dye and staining agent in medicine. The application of alizarin dye and its derivatives in DSSCs was investigated theoretically [2,25].

a)<smiles>O=C1C=C2OC3C=C(O)C(O)CC3C(c3ccccc3)=C2C=C1O</smiles>

b)<smiles>O=C1C=CC(=C(c2ccc(O)c(O)c2)c2ccccc2S(=O)(=O)[O-])C=C1O</smiles>

c)<smiles>O=C1c2ccccc2C(=O)c2c1ccc(O)c2O</smiles>

Figure 1. The chemical structure of the dye molecules: (a) PF, (b) PCV, (c) AL.

The enediol group of the catechol ring occurring in all the structures of the dyes studied in this work is known for making a chelating bond with titanium in $\mathrm{TiO}_{2}$, giving rise to a new absorption band corresponding to the charge transfer mechanism with very fast electron injection to the $\mathrm{TiO}_{2}$ semiconductor conduction band [2,26-28]. Recently, it was demonstrated that upon photoexcitation, the presence of a catechol unit enhances the electron injection to the $\mathrm{TiO}_{2}$ semiconductor [29].

In addition to the investigation of the aforementioned dyes as photosensitizers in DSSCs, this work presents the influence of the back reflective layer (RL) on the performance 
of the prepared dye cells, with the aim to exploit the transmitted light (crossing the cell). In this study, barium sulfate $\left(\mathrm{BaSO}_{4}\right)$ was implemented as the reflective layer on the back side of the cell, with diffuse reflectance exceeding 95\% in the wavelength of 200-1800 nm [30]. This kind of material scatters light so diffuse photons can be trapped inside the solar cell structure, which is advantageous for the cell operation.

\section{Materials and Methods}

All chemicals were purchased commercially and used without further purification. The glass electrodes with fluorine tin oxide (FTO) conductive coverage, the counter electrodes covered with platinum black and the $\mathrm{I}^{-} / \mathrm{I}_{3}-$ liquid electrolyte were purchased from the Greatcell Solar company. The glass FTO electrodes of $2 \times 2.5 \mathrm{~cm}$ size and $18 \Omega / \mathrm{sq}$ sheet resistance were cleaned in acetone and ethanol, dried in nitrogen gas flow and employed as substrates for the layer of the titanium dioxide paste. The preparation of paste included several steps [31] in which the $\mathrm{TiO}_{2}$ nanoparticles $\mathrm{P} 25$ from Degussa were used. The $\mathrm{TiO}_{2}$ paste was deposited on glass electrodes with doctor blade method and then annealed at $450{ }^{\circ} \mathrm{C}$ to sinter the nanoparticles. The electrodes covered with $\mathrm{TiO}_{2}$ were immersed in $2 \mathrm{mM}$ solutions of phenylfluorone, pyrocatechol violet, and alizarin dyes in absolute ethanol for 1, 2, 24 or $48 \mathrm{~h}$ in darkness at room temperature, and then the sensitized electrodes were rinsed with absolute ethanol. The $\mathrm{TiO}_{2}$ working electrode and counter electrode were assembled with Surlyn separator and sealed in a Gestigkeit PZ 28-3T (Inverness, UK) high-temperature titanium hot plate with a lid. The electrolyte was introduced through the holes in the Pt-coated electrode. The active area of the cells was $0.8 \mathrm{~cm}^{2}$. Figure 2 shows the schematic illustration of the dye cell. The cells were examined in a solar light simulator (Abet Technologies SUN 3000, Sydney, Australia) under $100 \mathrm{~mW} / \mathrm{cm}^{2}$ illumination, and I-V curves were obtained on a Keithley 2440 Source Measure Unit. The measurements were repeated 3-6 times for a minimum of 3 cells of the same type. The absorption and reflectance spectra of dyes or electrodes were measured by using a Thermo Scientific Evolution 220 UV-Vis (Darmstadt, Germany) spectrophotometer equipped with ISA-220 integrating sphere. The morphology of the $\mathrm{TiO}_{2}$ layer was determined by using a Hitachi SU 3500 scanning electron microscope (SEM).

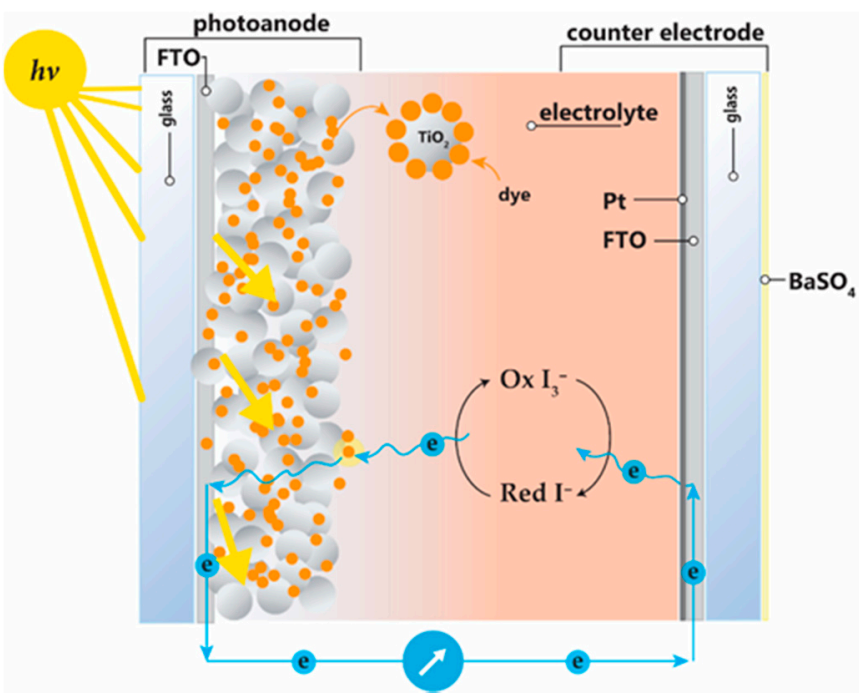

Figure 2. Schematic illustration of the dye cell.

In order to investigate the effect of the back reflective layer, the prepared semitransparent cells were placed on a $\mathrm{BaSO}_{4}$ powder layer, and the measurements of I-V curves were performed under the simulated light. 


\section{Results}

\subsection{Characterization of Photoelectrode}

The morphology of the $\mathrm{TiO}_{2}$ nanoparticle layer deposited on the glass electrode and sintered at high temperature is shown in Figure 3a. The SEM image reveals the mesoporous structure of the layer, which is essential to ensure penetration of the dye solution and electrolyte between nanoparticles. The coverage of $\mathrm{TiO}_{2}$ by the adsorbed dye is visible in Figure $3 b$.

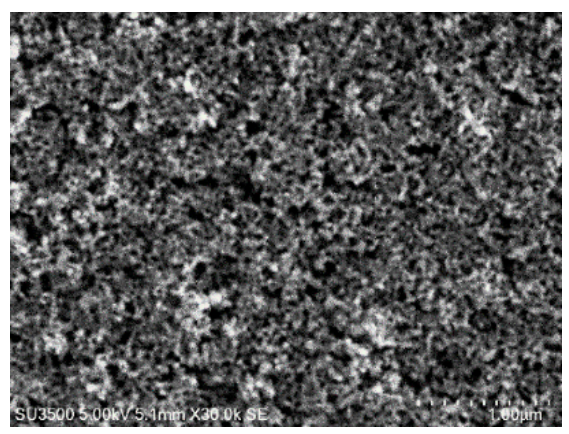

(a)

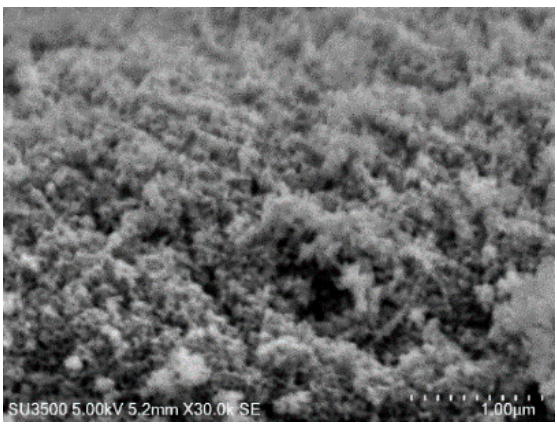

(b)

Figure 3. (a) SEM image of mesoporous bare $\mathrm{TiO}_{2}$ layer, (b) SEM image of $\mathrm{TiO}_{2}$ layer with the alizarin dye adsorbed after the soaking of the electrode in $2 \mathrm{mM}$ ethanol solution for $24 \mathrm{~h}$.

The $\mathrm{TiO}_{2}$ layer exhibits the ability to scatter the incident light, which is beneficial for enhancing the light harvesting. The diffuse reflectance of $\mathrm{TiO}_{2}$ layer shown in Figure 4 achieves over $40 \%$ in the range of $400-530 \mathrm{~nm}$.

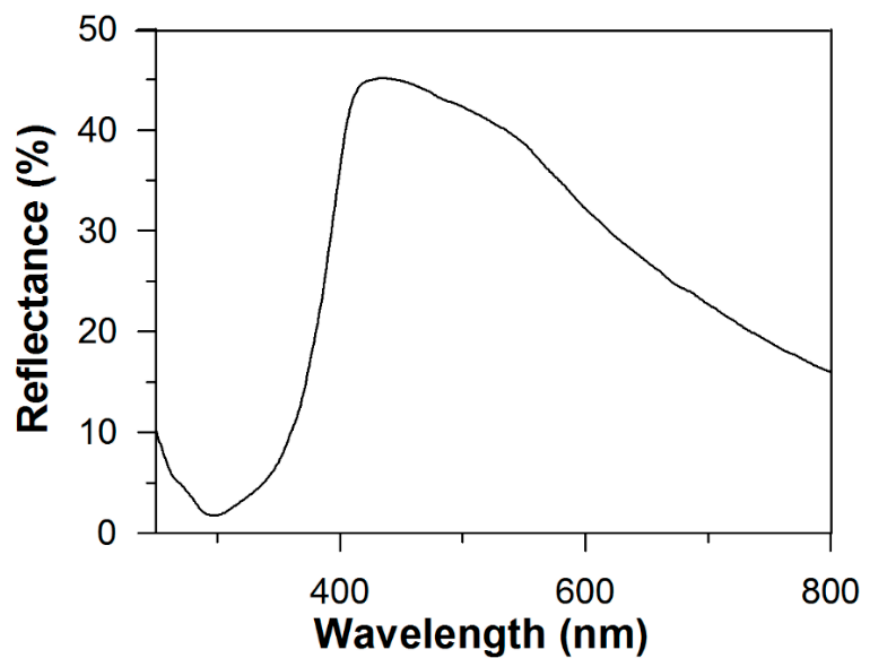

Figure 4. Diffuse reflectance of a photoelectrode covered by $\mathrm{TiO}_{2}$.

Immersion of fabricated photoelectrodes in solutions of dyes results in the intensive tint of the titanium dioxide layer, which is visible in Figure 5. Each electrode shown in Figure 5 was immersed in a dye solution for the optimal time selected for a given dye, leading to the best photovoltaic performance (v.i.). 


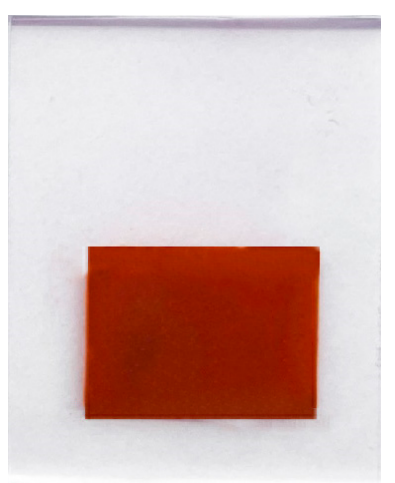

(a)

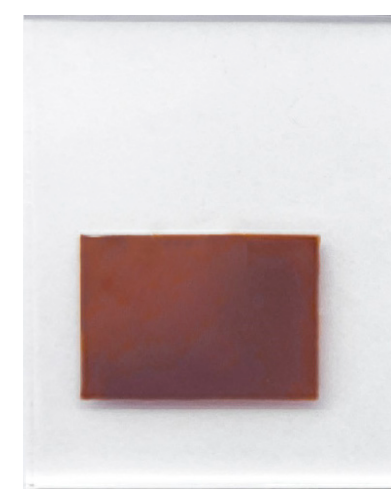

(b)

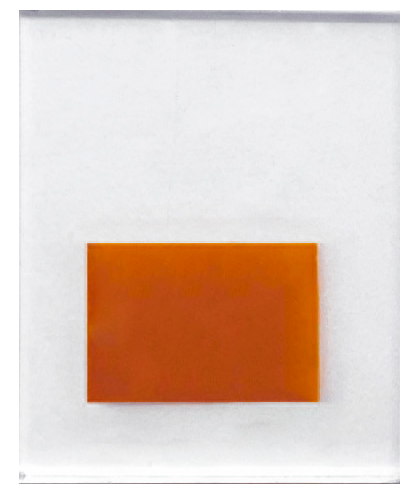

(c)

Figure 5. Photos of $\mathrm{TiO}_{2}$ photoelectrodes after the immersion in the solution of (a) $2 \mathrm{mM}$ PF in ethanol, $2 \mathrm{~h}$ soaking time; (b) $2 \mathrm{mM}$ PCV in ethanol, $1 \mathrm{~h}$ soaking time; and (c) $2 \mathrm{mM}$ AL in ethanol, $2 \mathrm{~h}$ soaking time.

\subsection{Photoelectrical Properties of the Dyes}

The sensitizing compound used in a DSSC should absorb light, preferably in a broad range of the visible spectrum. In order to verify the coverage of the light spectrum by the investigated dyes, especially after the process of adsorption on $\mathrm{TiO}_{2}$ nanoparticles, the absorption measurements were performed. The absorption spectra in Figure 6 show that free PF dye solution in ethanol exhibits only a narrow absorption band around $520 \mathrm{~nm}$; however, upon adsorption on $\mathrm{TiO}_{2}$ nanostructural coverage of electrodes, a significant broadening of the absorption range occurs. In consequence, the absorption covers a variety of wavelengths from around 400 to $600 \mathrm{~nm}$. Below $400 \mathrm{~nm}$, the absorption of bare $\mathrm{TiO}_{2}$ is observed.

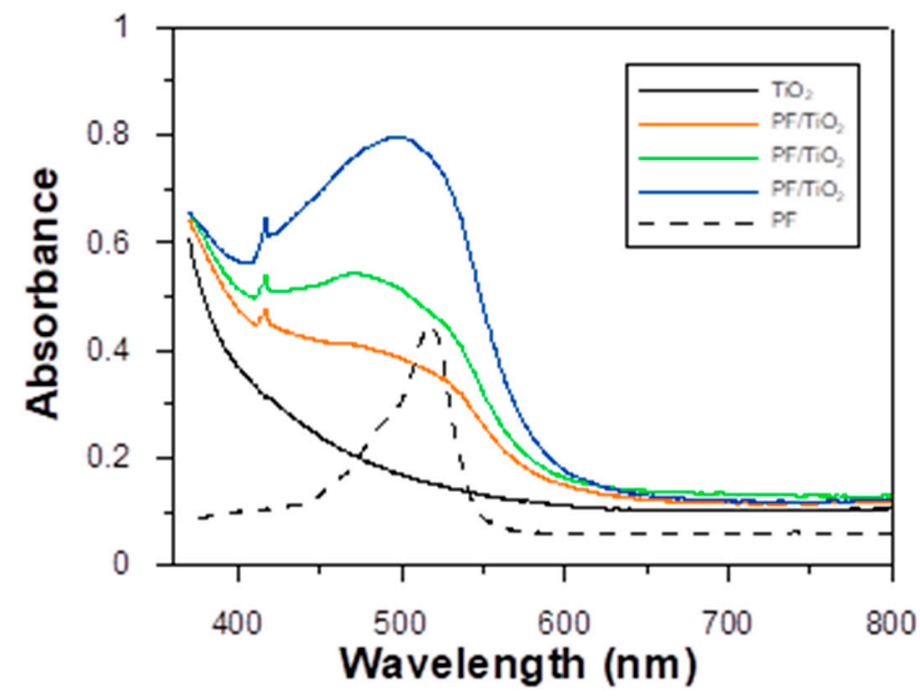

Figure 6. Absorbance spectra of the PF solution, $\mathrm{PF}$ adsorbed on $\mathrm{PF} / \mathrm{TiO}_{2}$ complex and bare $\mathrm{TiO}_{2}$ photoelectrode.

The absorption spectrum of PCV in free form in an ethanol solution consists of two bands: one with a maximum around $450 \mathrm{~nm}$ and the second, much weaker, band at $575 \mathrm{~nm}$ (Figure 7). The adsorption of $\mathrm{PCV}$ on $\mathrm{TiO}_{2}$ leads to the broadening of the absorption range that covers the visible spectrum nearly to $700 \mathrm{~nm}$. 


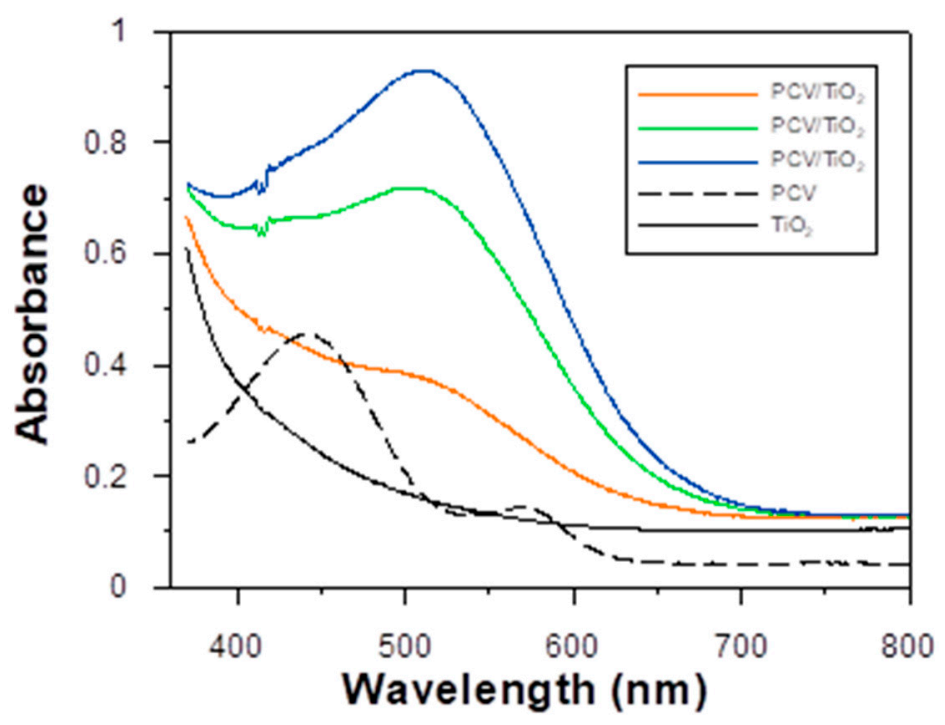

Figure 7. Absorbance spectra of the PCV solution, $\mathrm{PCV}$ adsorbed on $\mathrm{PCV} / \mathrm{TiO}_{2}$ complex and bare $\mathrm{TiO}_{2}$ photoelectrode.

Free alizarin absorbs light up to $500 \mathrm{~nm}$ with the maximum at about $440 \mathrm{~nm}$, which is shown in Figure 8. Binding of AL to $\mathrm{TiO}_{2}$ causes the shift to $500 \mathrm{~nm}$ and broadening with the band wing extending to over $600 \mathrm{~nm}$.

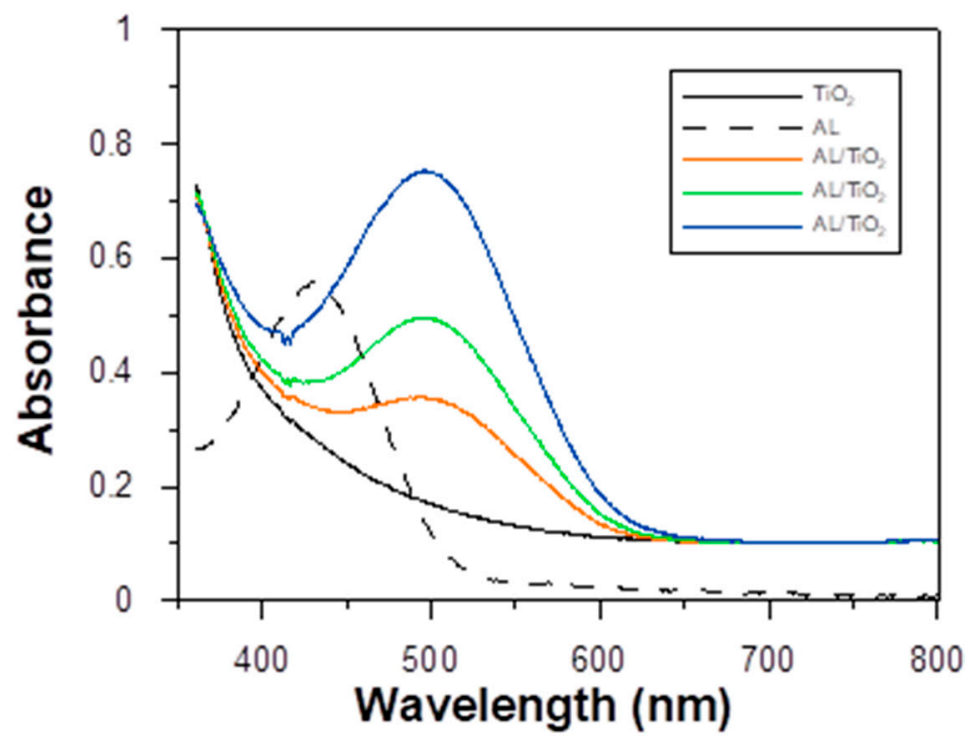

Figure 8. Absorbance spectra of the $\mathrm{AL}$ solution, $\mathrm{AL}$ adsorbed on $\mathrm{AL} / \mathrm{TiO}_{2}$ complex and bare $\mathrm{TiO}_{2}$ photoelectrode.

The observed broadening of absorption spectrum upon adsorption of the tested dyes on nanoparticles implies that they may exhibit prominent optical properties as sensitizers in DSSCs.

Each of the Figures 6-8 presents several curves (colored solid lines) corresponding to the absorption spectra of the dye $/ \mathrm{TiO}_{2}$ complex for different times of soaking the $\mathrm{TiO}_{2}$ electrode in the dye solution. The possible concentration-dependent band shifts determined for the spectra with increasing dye load did not exceed $3 \mathrm{~nm}$ for all three investigated dyes, which does not exceed the experimental accuracy with these broad bands. No significant spectral effects occur in the examined electrodes, and thus the aggregation of dye molecules was not considered. 


\section{3. $\mathrm{TiO}_{2} /$ Dye/Electrolyte Interface}

The electron transfer from the sensitizing dye to $\mathrm{TiO}_{2}$ nanoparticles requires the LUMO level of the dye to be more reducing than the conduction band of a semiconductor. Analogously, in the process of the regeneration of dye ground state, the dye cation is required to be more oxidizing than the $\mathrm{I}^{-} / \mathrm{I}_{3}{ }^{-}$redox couple.

Using the oxidation potential of the PF, PCV and AL molecules [25,32], the HOMO levels were determined in $\mathrm{eV}$ according to the absolute energy scale. The LUMO orbital $\left(E_{\text {LUMO }}\right)$ was calculated as a sum of HOMO energy $\left(E_{H O M O}\right)$ and transition energy $\left(E^{0-0}\right)$ at the absorption maximum of the dye adsorbed on $\mathrm{TiO}_{2}$ nanoparticle, according to the following relation:

$$
E_{\text {LUMO }}=E_{\text {HOMO }}+E^{0-0},
$$

Table 1 presents the calculated values of the HOMO and LUMO energy levels.

Table 1. $\mathrm{HOMO}$ and LUMO of the dye- $\mathrm{TiO}_{2}$ complexes calculated after the adsorption process.

\begin{tabular}{ccccccc}
\hline Dye & $\begin{array}{c}\lambda(\mathrm{nm}) \text { at } \\
\text { Max Abs. }\end{array}$ & $\boldsymbol{E}^{\mathbf{0}-\mathbf{0}(\mathrm{eV})}$ & $\begin{array}{c}E_{\text {HOMO }} \\
(\mathrm{eV})\end{array}$ & $\begin{array}{c}E_{\text {LUMO }} \\
(\mathrm{eV})\end{array}$ & $\boldsymbol{\Delta} G_{\text {inj }}(\mathrm{eV})$ & $\boldsymbol{\Delta} \boldsymbol{G}_{\text {reg }}(\mathrm{eV})$ \\
\hline $\mathrm{PF}$ & 498 & 2.49 & -5.58 & -3.09 & 1.21 & 0.78 \\
$\mathrm{PCV}$ & 511 & 2.426 & -5.5 & -3.074 & 1.23 & 0.70 \\
$\mathrm{AL}$ & 500 & 2.48 & -6.23 & -3.75 & 0.55 & 1.43 \\
\hline
\end{tabular}

Particular energy levels, the positions of which are crucial for the operation of the dye-sensitized cell, are depicted in Figure 9. The arrangement of the HOMO and LUMO levels of the investigated dyes in relation to the bottom of the $\mathrm{TiO}_{2}$ conduction band and redox potential of the electrolyte is suitable for an efficient transfer of electrons in the working cycle of the dye cell. The differences between the positions of HOMO, LUMO, $E_{C B}$ and electrolyte redox level $E_{e l}$ enable the determination of the parameters that quantitatively describe the electron transfer reactions: free energy driving force $\Delta G_{i n j}$ and electron regeneration driving force $\Delta G_{\text {reg }}$ (Table 1), according to the following equations [33]:

$$
\begin{gathered}
\Delta G_{i n j}=E_{L U M O}-E_{C B}, \\
\Delta G_{r e g}=E_{\text {HOMO }}-E_{e l} .
\end{gathered}
$$

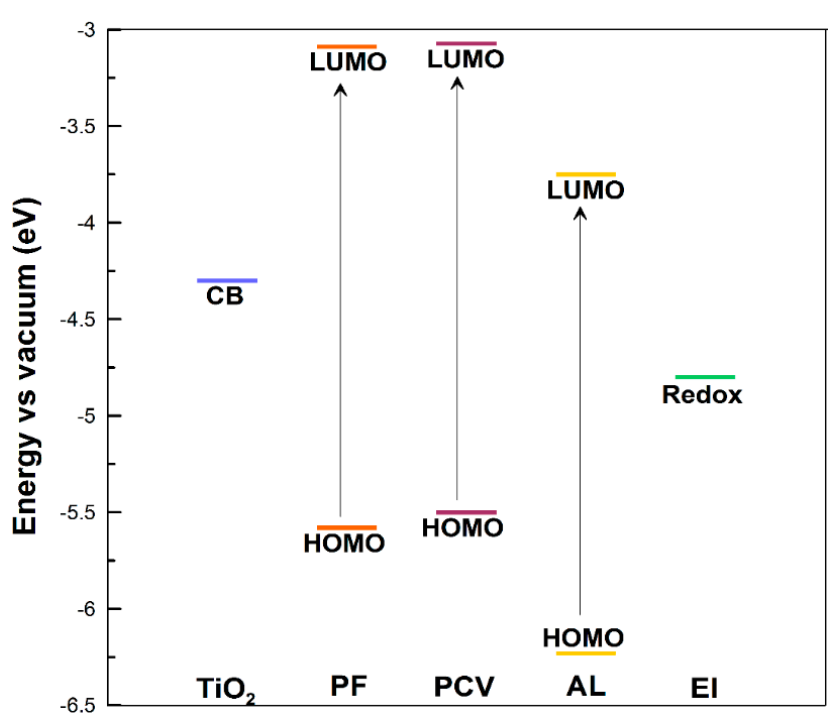

Figure 9. Scheme of the energy levels of $\mathrm{PF} / \mathrm{TiO}_{2}, \mathrm{PCV} / \mathrm{TiO}_{2}, \mathrm{AL} / \mathrm{TiO}_{2}, \mathrm{TiO}_{2}$ and $\mathrm{I}^{-} / \mathrm{I}_{3}{ }^{-}$electrolyte redox potential. 
The photoelectric properties of the studied dyes were also evaluated by the determination of the chemical reactivity parameters, including chemical potential, global hardness and electrophilicity (Table 2).

Table 2. Chemical reactivity parameters of the dyes.

\begin{tabular}{cccc}
\hline Dye & $\mu(\mathrm{eV})$ & $\eta_{g}(\mathrm{eV})$ & $\omega(\mathrm{eV})$ \\
\hline PF & 4.335 & 1.245 & 7.545 \\
PCV & 4.287 & 1.213 & 7.575 \\
AL & 4.99 & 1.24 & 10.04 \\
\hline
\end{tabular}

Chemical potential $\mu$ reflects the escaping tendency of an electron from equilibrium and is connected with rearrangement of electrons in chemical phenomena [34]:

$$
\mu=\left(\frac{\partial E}{\partial N}\right)_{v(\vec{r})},
$$

$\mu=-\chi$, where $\chi$ is the electronegativity, $E$ is the total energy of an atom or molecule in the ground state and $N$ is the number of electrons.

Global hardness $\eta_{g}$ expresses the resistance to electron transfer (equilibrium of the system corresponds to maximum hardness) and can be calculated according to the following formula:

$$
\eta_{g}=\frac{1}{2}\left(\frac{\partial^{2} E}{\partial N^{2}}\right)_{v(\vec{r})} .
$$

The approximation based on Koopman's theorem, successfully used for different kinds of organic and inorganic molecules [34,35], leads to the following formulas expressing $\mu$ and $\eta_{g}$, which are related directly to the HOMO and LUMO energies:

$$
\begin{aligned}
\mu & \approx \frac{1}{2}\left(E_{\text {LUMO }}+E_{\text {HOMO }}\right), \\
\eta_{g} & \approx \frac{1}{2}\left(E_{\text {LUMO }}-E_{\text {HOMO }}\right) .
\end{aligned}
$$

Electrophilicity index $\omega$ is also one of the descriptors of reactivity that corresponds to the balance energy of a system saturated by electrons; thus, it is a measure of energy lowering due to transfer of electrons between donor and acceptor $[34,36,37]$ :

$$
\omega=\frac{\mu^{2}}{2 \eta_{g}} \approx \frac{\left(E_{L U M O}+E_{H O M O}\right)^{2}}{4\left(E_{L U M O}-E_{\text {HOMO }}\right)} .
$$

Global hardness is the highest for PF; however, the differences in values for other compounds are small. The chemical potential values of PF and PCV are around $4.3 \mathrm{eV}$, close to $\mathrm{TiO}_{2}$ anatase, which is described further in Section 4.

\subsection{Photovoltaic Performance}

The performance of the dye-sensitized solar cell is characterized by such electric parameters as short-circuit current $\left(I_{S C}\right)$, open-circuit voltage $\left(V_{O C}\right)$, current and voltage at maximum power $\left(P_{M P}\right)$ and fill factor $(F F)$ and efficiency $(\eta)$ of the cell. The last two parameters are calculated according to the following formulas [38]:

$$
\begin{gathered}
F F=\frac{P_{M P}}{V_{O C} I_{S C}}=\frac{V_{M P} I_{M P}}{V_{O C} I_{S C}} \\
\eta=\frac{P_{M P}}{P_{\text {in }}}=\frac{V_{M P} I_{M P}}{P_{\text {in }}},
\end{gathered}
$$


where $V_{M P}$ is voltage at maximum power point, $I_{M P}$ is current at maximum power point and $P_{\text {in }}$ is the incident light power.

Figures $10-12$ present the density of current vs. voltage $(J-V)$ characteristics, including the measurements performed with the $\mathrm{BaSO}_{4}$ reflective layer (RL) on the back side of the dye cells. The electric parameters derived from the characteristics of the investigated photocells are listed in Table 3. The results presented in Table 3 include the parameters obtained for different times of the photoelectrode immersion in the dye solution. The optimal time in terms of efficiency was determined for each type of dye and is indicated in Table 3. The maximum efficiency of the cells with PF and AL is one order of magnitude greater than that for PCV. The implementation of the back reflective layer provides better results for all tested cells. In the case of the PF dye, the improvement of even $17.9 \%$ in efficiency (for $2 \mathrm{~h}$ dipping time) is observed due to the reflection of light from the $\mathrm{BaSO}_{4}$ layer. The same tendency is visible for the cells with PCV, the efficiency of which is $60 \%$ better (for $1 \mathrm{~h}$ dipping time) than in the measurements without reflective layer. For alizarin, the best parameters of the cells were obtained after $2 \mathrm{~h}$ soaking time, and a $21.4 \%$ increase in efficiency was observed with the use of the $\mathrm{BaSO}_{4}$ reflective layer.

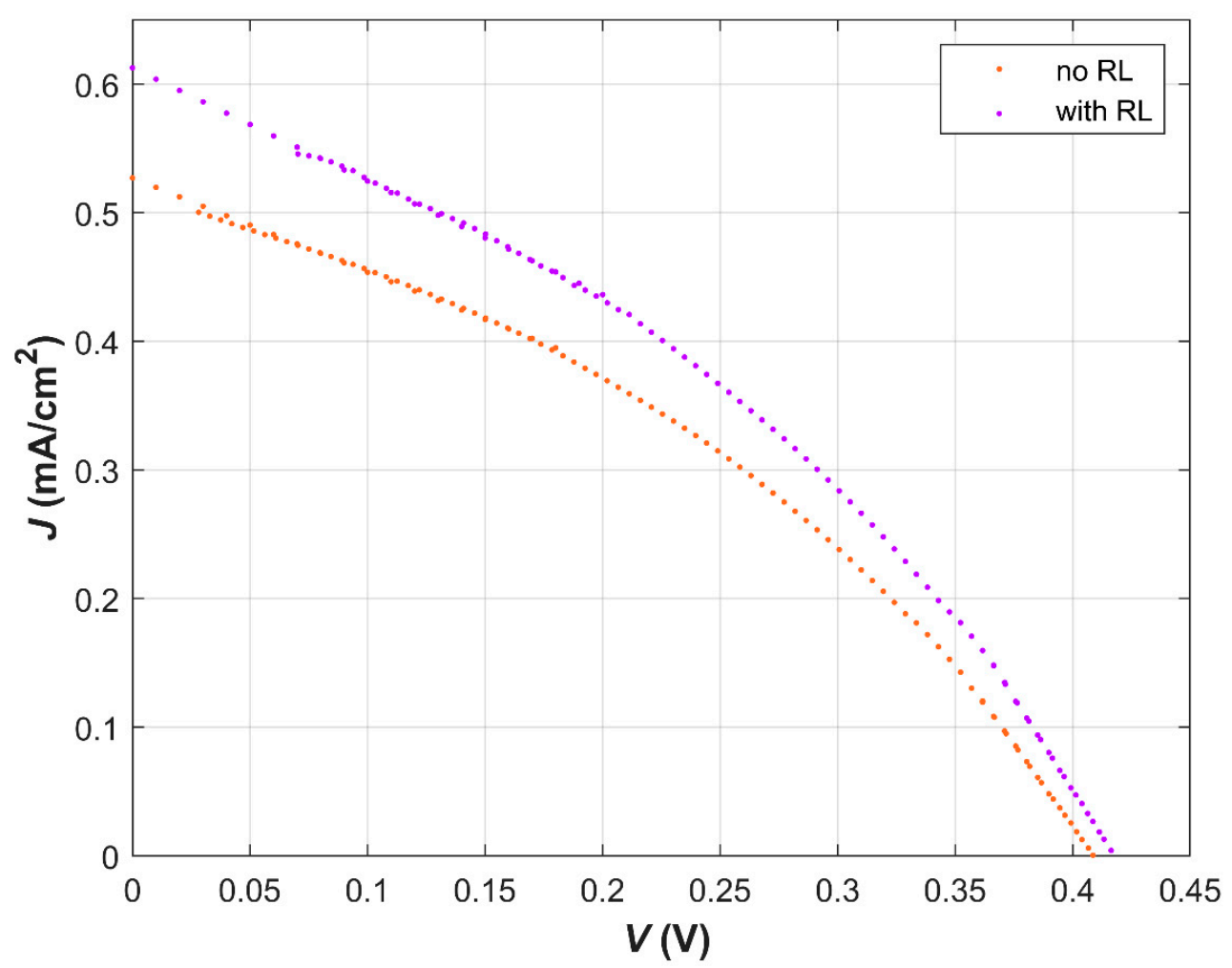

Figure 10. The $J-V$ characteristics of the PF-sensitized dye cells ( $2 \mathrm{~h}$ immersion time), measured without the reflective layer (no RL) and with the reflective layer (with RL). 


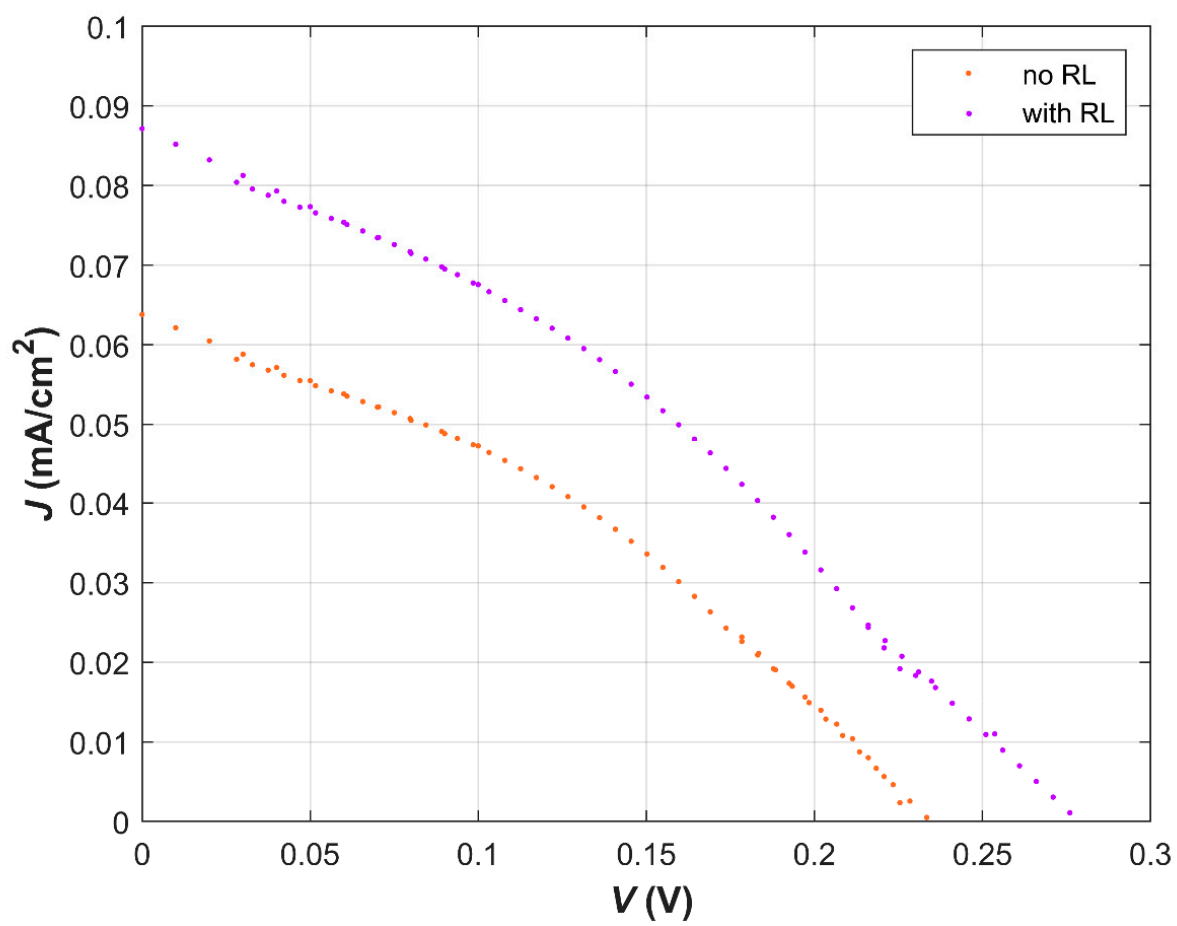

Figure 11. The $J-V$ characteristics of the PCV-sensitized dye cells ( $1 \mathrm{~h}$ immersion time), measured without the reflective layer (no RL) and with the reflective layer (with RL).

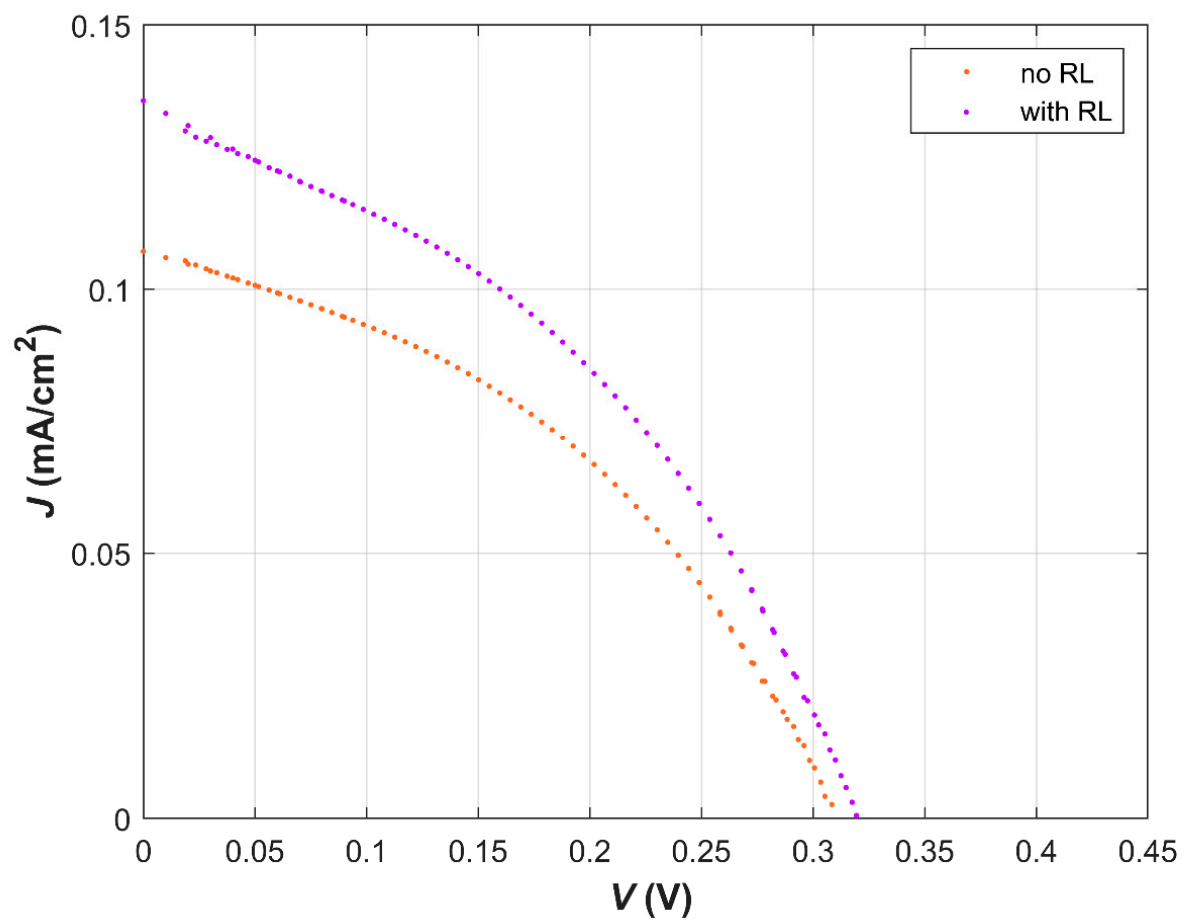

Figure 12. The $J-V$ characteristics of the AL-sensitized dye cells ( $2 \mathrm{~h}$ immersion time), measured without the reflective layer (no RL) and with the reflective layer (with RL). 
Table 3. Parameters of the DSSCs sensitized with PF, PCV and AL for different dipping times obtained with or without the reflective layer (RL). The best values obtained for each dye are indicated in bold.

\begin{tabular}{|c|c|c|c|c|c|}
\hline \multicolumn{6}{|c|}{ PF } \\
\hline & $\begin{array}{l}\text { Dipping } \\
\text { Time (h) }\end{array}$ & $\begin{array}{c}J_{S C} \\
\left(\mathrm{~mA} / \mathrm{cm}^{2}\right)\end{array}$ & $V_{O C}(\mathrm{mV})$ & $\begin{array}{c}\text { Efficiency } \\
(\%)\end{array}$ & $F F(\%)$ \\
\hline No RL & 1 & 0.24 & 389.5 & 0.038 & 42.10 \\
\hline With RL & 1 & 0.29 & 404.5 & 0.048 & 41.47 \\
\hline No RL & 2 & 0.53 & 406.4 & 0.078 & 36.6 \\
\hline With RL & 2 & 0.61 & 414.9 & 0.092 & 36.1 \\
\hline No RL & 24 & 0.37 & 430.8 & 0.056 & 35 \\
\hline With RL & 24 & 0.40 & 437.4 & 0.062 & 35.3 \\
\hline No RL & 48 & 0.30 & 386.7 & 0.049 & 42.58 \\
\hline With RL & 48 & 0.37 & 403.5 & 0.062 & 42.17 \\
\hline \multicolumn{6}{|c|}{ PCV } \\
\hline & $\begin{array}{l}\text { Dipping } \\
\text { Time (h) }\end{array}$ & $J_{S C}\left(\mathrm{~mA} / \mathrm{cm}^{2}\right)$ & $V_{O C}(\mathrm{mV})$ & $\begin{array}{c}\text { Efficiency } \\
(\%)\end{array}$ & $F F(\%)$ \\
\hline No RL & 0.5 & 0.063 & 208.9 & 0.002 & 18.84 \\
\hline With RL & 0.5 & 0.067 & 227.0 & 0.004 & 25.23 \\
\hline No RL & 1 & 0.069 & 228.4 & 0.005 & 33.44 \\
\hline With RL & 1 & 0.092 & 266.7 & 0.008 & 32.6 \\
\hline No RL & 2 & 0.077 & 216.4 & 0.004 & 27.14 \\
\hline With RL & 2 & 0.089 & 251.6 & 0.007 & 31.12 \\
\hline No RL & 24 & 0.078 & 182.9 & 0.003 & 22.26 \\
\hline With RL & 24 & 0.084 & 206.4 & 0.005 & 26.66 \\
\hline No RL & 48 & 0.087 & 119.1 & 0.002 & 18.64 \\
\hline With RL & 48 & 0.1 & 151.5 & 0.003 & 19.67 \\
\hline \multicolumn{6}{|c|}{ AL } \\
\hline & $\begin{array}{l}\text { Dipping } \\
\text { Time (h) }\end{array}$ & $J_{S C}\left(\mathrm{~mA} / \mathrm{cm}^{2}\right)$ & $V_{O C}(\mathrm{mV})$ & $\begin{array}{c}\text { Efficiency } \\
(\%)\end{array}$ & $F F(\%)$ \\
\hline No RL & 1 & 0.076 & 279.8 & 0.008 & 37.24 \\
\hline With RL & 1 & 0.086 & 289.4 & 0.009 & 37.13 \\
\hline No RL & 2 & 0.112 & 308.2 & 0.014 & 39.14 \\
\hline With RL & 2 & 0.138 & 318.1 & 0.017 & 38.79 \\
\hline No RL & 24 & 0.078 & 284.6 & 0.008 & 37.34 \\
\hline With RL & 24 & 0.083 & 288.1 & 0.009 & 37.33 \\
\hline No RL & 48 & 0.105 & 128.7 & 0.002 & 16.31 \\
\hline With RL & 48 & 0.11 & 130.2 & 0.003 & 18 \\
\hline
\end{tabular}

The values of open-circuit voltage are in the range of 387-437 mV for PF, 119-267 mV for PCV and $128-318 \mathrm{mV}$ for AL. The shape of the curves is properly bent; however, the internal resistances occurring in the cells lead to an efficiency decrease.

The performance parameters of the investigated cells can be related to the values reported previously for the cell prepared according to the same methodology based on the N719 dye [39]. The cell sensitized with N719, which can be recognized in this work as the reference cell, provided $J_{S C}=12.29 \mathrm{~mA} / \mathrm{cm}^{2}, V_{O C}=713 \mathrm{mV}$ and the efficiency of $5.03 \%$ in the measurements without the reflective $\mathrm{BaSO}_{4}$ layer. The implementation of the $\mathrm{BaSO}_{4}$ reflective layer in the reference cell based on N719 resulted in the improvement of the following photovoltaic parameters: $J_{S C}=14.71 \mathrm{~mA} / \mathrm{cm}^{2}, V_{O C}=722 \mathrm{mV}$ and the efficiency of $5.82 \%$, which confirmed the beneficial role of the reflective layer also in the cells with the well-known, efficient sensitizer.

The values of standard deviations of efficiency, determined for the best cells (indicated in bold in Table 3) are as follows: 0.001466 (PF no RL) and 0.000358 (PF with RL), 0.00046 (PCV no RL) and 0.00024 (PCV with RL), 0.00029 (AL no RL) and 0.00022 (AL with RL). 
In order to compare the performance of the studied dyes, the absorption of light was analyzed in relation to $J_{S C}$, which is strongly influenced by the amount of absorbed photons. Figure 13 presents the dependency of absorbance at the absorption maximum, measured for the electrodes covered by $\mathrm{TiO}_{2}$ and immersed in dye solution for the optimized time ( $2 \mathrm{~h}$ in case of PF and AL, $1 \mathrm{~h}$ in case of PCV), versus the short-circuit current density obtained for the cells prepared with these electrodes. The plot in Figure 13 shows that the higher absorbance is accompanied by the greater photocurrent, and the best-performing dye, $\mathrm{PF}$, stands out in terms of both parameters.

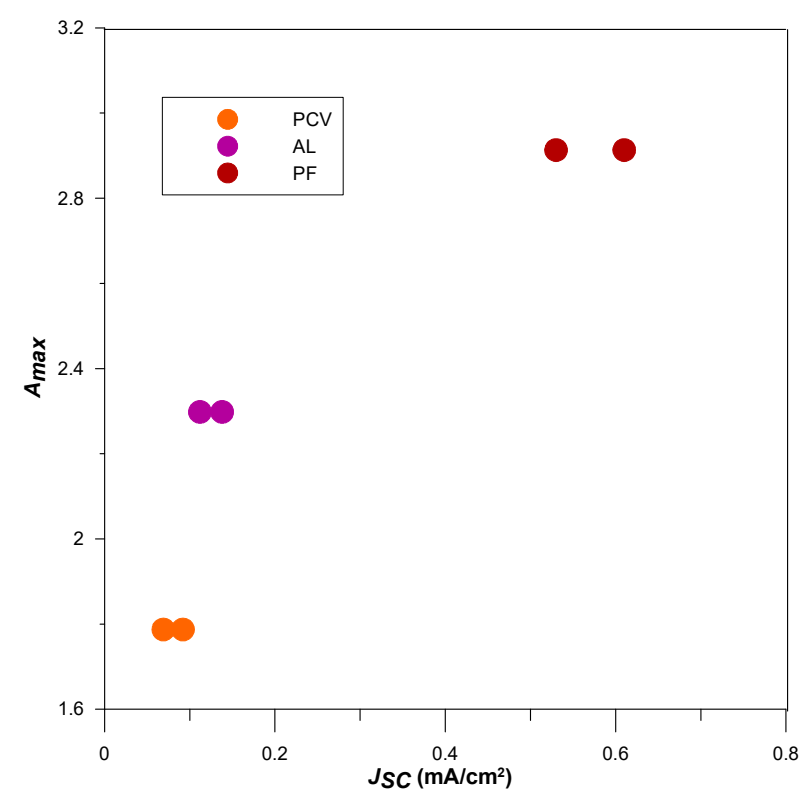

Figure 13. Absorbance at the absorption maximum measured for the photoelectrodes immersed in dye solution for the optimized time ( $2 \mathrm{~h}$ in case of PF and AL, $1 \mathrm{~h}$ in case of PCV) vs. the short-circuit current density for the dye cells with PF, PCV and AL. There are two points for each dye: one corresponds to the cell without the back reflecting layer, and the other corresponds to the cell with the reflective layer.

For the cells with optimized immersion time, the parasitic resistances were also determined. The series resistance is in the range of 542-602 $\Omega$ for cells sensitized with PF, 2617-2954 $\Omega$ for PCV and 1416-1611 $\Omega$ for AL, with RL and without RL. Shunt resistance value is $1562 \Omega$ for cells sensitized with PF, 6250-6666 $\Omega$ for PCV and 5000-6944 $\Omega$ for AL.

\section{Discussion}

The performance of DSSCs depends on numerous factors, including the types of materials used and the structure of the cells. This work is devoted to the application of three different sensitizers and the implementation of the back reflective layer, which raises the chances of absorbing the light that passes through the cell. It is advisable to return the light back to the cell when the cell absorption is relatively poor and also to use the light out of the absorption range.

The photoelectrodes used in the investigated DSSCs, prepared by deposition of the $\mathrm{TiO}_{2}$ paste, exhibited porous structures suitable for adsorption of the dye. The observed light-scattering ability of the $\mathrm{TiO}_{2}$ layer can enable better capturing of the light. The diffuse reflectance of the prepared $\mathrm{TiO}_{2}$ layer is relatively high in comparison to a lower value of $25 \%$ or narrow reflectance range in the literature $[40,41]$.

The dyes introduced in the dye cells as sensitizers should adsorb on titanium dioxide nanoparticles making a durable bond. The UV-Vis spectroscopy measurements presented in this work confirmed the ability of phenylfluorone, pyrocatechol violet and alizarin to chelate titanium. Similar effects were observed in the studies on the creation of complexes 
with other metal ions. Phenylfluorone was reported to create a complex with antimony, the features of which were investigated by UV-Vis and Raman spectroscopy, revealing the possibility of application for detection and quantitative determination of the antimony content in toxicology [42]. The material functionalized with PF was also used for cadmium and copper determination in water samples [43]. PCV as a catechol-like compound was proven to be a good ligand for metal ions; e.g., the ligand-exchange reaction of PCV coordinated to $\mathrm{Zr}(\mathrm{IV})$ has been observed [44]. In this kind of reaction, the yellow color changes to blue depending on $\mathrm{pH}$, and the absorption is shifted from 440 to $630 \mathrm{~nm}$. Not only Zr but also Ti was reported to form stable complexes with PCV. The titanium alkoxide compound allowed simple preparation of HF-sensitive PCV-Ti complex that changes color upon exposure to the HF vapor [45]. In the literature, the spectra of alizarin- $\left(\mathrm{TiO}_{2}\right)_{15}$ complex were modeled, and the ultrafast electron transfer dynamics of alizarin adsorbed to a colloidal titanium oxide nanocrystallite was investigated theoretically [46].

In order to achieve fast electron injection and regeneration of the oxidized dye, an efficient sensitizer is supposed to possess the ground state below the redox potential of the electrolyte and excited state over the edge of $\mathrm{TiO}_{2}$ conduction band. This fundamental requirement is fulfilled by all three studied dyes (PF, PCV, $\mathrm{AL}$ ). Moreover, all three dyes bind to $\mathrm{TiO}_{2}$ in the same bidentate chelating configuration by the enediol ring; this circumstance provides a similar energy barrier for electron injection in each case and leaves the energetics of electron transfer as the main determinant of the process.

In general, it is assumed that greater $\Delta G_{i n j}$ leads to more effective electron transfer, contrary to $\Delta G_{\text {reg }}$ for which lower values are beneficial [47,48]. Taking into account these rules, $\Delta G_{i n j}$ and $\Delta G_{r e g}$ of PCV and PF have the best values. However, the photovoltaic performance of PCV is the worst among the studied dyes. The possible aggregation of PCV molecules, revealed especially for longer dipping times, that results in worsened photovoltaic parameters, may suppress the effective electron injection process. In the literature, the $\Delta G_{i n j}$ value greater than $0.2 \mathrm{eV}$ is recommended [25]; however, for one of the most efficient sensitizers, N719, the driving force is equal to $0.15 \mathrm{eV}$ [38]. In terms of $\Delta G_{\text {reg }}$, the value of $0.2-0.3 \mathrm{eV}$ is required for electron recombination for ruthenium dyes by oxidation of iodide/triiodide electrolyte [38].

Nevertheless, the consideration of various literature data and the results of this study do not provide a clear and strict recipe that determines the best configuration of $\mathrm{HOMO}$ and LUMO positions of dye molecules in DSSCs. Taking into account the driving force values mentioned above and their connection with the Marcus theory of electron transfer [49], it can be assumed that an increase in $\Delta G_{i n j}$ is beneficial to some upper limit. Further increase in the difference between the LUMO of the dye and semiconductor bandgap edge can result in the suppression of the DSSC efficiency according to the Marcus inverted regime. However, Marcus theory is devoted to proteins and dye molecules taking part in photosynthesis, and its reference to the dye molecules adsorbed on solid state may not be straightforward.

The chemical reactivity parameters determined in this work present beneficial values for $\mathrm{PF}$, since the greater global hardness and the smaller electrophilicity lead to the higher efficiency of DSSCs [34]. In general, the photosensitizers best suited for titanium dioxide surface should present good matching of both electronegativity and the global hardness to the parameters of $\mathrm{TiO}_{2}$ anatase, equaling 4.3 and $1.6 \mathrm{eV}$, respectively [50], which is achieved in this work.

The photovoltaic performance of the solar cells sensitized with three tested dyes exhibits the best values for the PF compound. The value of $V_{O C}$ over $0.4 \mathrm{~V}$ achieved in this work is satisfactory taking into account $V_{O C}$ of $0.33-0.64 \mathrm{~V}$ for natural dyes [22] or $0.254-0.691 \mathrm{~V}$ for the recently designed ruthenium complexes [51]. The $J-V$ curves of dye cells with PF and AL exhibit also the proper shape, which is reflected in fill factor value of up to $39.14 \%$ (AL) and over $42 \%$ (PF) which is a good result compared to $27-69 \%$ for natural sensitizers [22] or $45-70 \%$ achieved for Ru complexes [51]. In general, any deterioration of the fill factor decreases the output power. The achieved values of $V_{O C}$ and 
FF are satisfactory; however, the current and in consequence efficiency of the investigated cells deserve improvement. In the literature, $\mathrm{ZnO}$-based DSSCs sensitized with fluorescein, the molecular structure of which is similar to phenylfluorone, show the efficiency of $6.54 \%$ and $0.55 \%$ with fluorinated fluorescein $[52,53]$.

For comparison, the literature study on pyranoflavylium salts possessing a catechol linker unit in the sensitizer molecule led to $1.15 \%$ efficiency in a DSSC with $\mathrm{TiO}_{2}$ and iodine electrolyte [29]. The trials involving other catecholate-functionalized compounds in DSSCs resulted in an efficiency of $0.92 \%$ [54].

Alizarin was applied in a DSSC before; however, it was a quasi-solid-state DSSC with a polymer electrolyte. After titanium tetrachloride treatment of the $\mathrm{TiO}_{2}$ layer, which improved the electron transport and dye molecule anchoring, an enhancement of the efficiency was achieved from 3.57 to $5.12 \%$ [55]. In the literature, the exposition of a photoanode, prepared by using P25 Degussa $\mathrm{TiO}_{2}$ nanoparticles sensitized with alizarin, to microwave radiation improved the efficiency of the cells from 0.14 to $0.16 \%$ [56]. The application of natural dyes such as alizarin usually leads to low efficiencies of $0.01-0.6 \%$ [57], $0.2-0.18 \%$ [58] and recently $0.197-0.878 \%$ in the investigation of natural plant extracts rich in luteolin [22]. The review of natural sensitizers shows the efficiency values of $0.008 \%$ for the $\mathrm{ZnO}$-based cells, $0.0083 \%$ and $0.301 \%$ for the $\mathrm{TiO}_{2}$-based cells, $0.516 \%$ for the cells with graphene-coated electrodes and 1.5\% in the cells sensitized with Rhus fruit extract [59]. The application of the anthocyanin dye provided a PCE of 2.9\% [59]. Low efficiency of $0.1-0.14 \%$ was also delivered by the cells sensitized with the dye extracted from chokeberry; however, the reference cell with N719 fabricated in that research provided $5.06 \%$ [60]. This value of efficiency is very close to the efficiency of the N719 reference cell used in this work, which amounts to $5.03 \%$.

The efficiency of solar energy conversion of the dye cells was enhanced in this study by applying the back reflective layer of $\mathrm{BaSO}_{4}$. The exhibited high efficacy of the reflected light may indicate that the electron transfer to the $\mathrm{TiO}_{2}$ nanoparticles located closer to the electrolyte is more efficient. The reason may be the faster regeneration of dye molecules that are in good contact with the electrolyte. In deeper parts of the $\mathrm{TiO}_{2}$ layer, near FTO, the reduction of dye molecules is limited due to the difficulty in electrolyte exchange by diffusion.

Back reflectors were typically introduced in thin-film silicon or copper gallium diselenide (CIGS) cells in order to improve light trapping in the cell. In thin-film silicon cells, other materials were also applied as a reflective layer: porous silicon dielectric layer [61], nanostructured $\mathrm{ZnO}$ and $\mathrm{Ag}$ [62] and polystyrene microspheres enhancing the short-circuit current and efficiency by over 30\% [63]. Commercial white paint containing $\mathrm{TiO}_{2}$ pigment also was used on the back side of a thin silicon cell, providing a short-circuit current density boost of 41\% [64]. In ultrathin CIGS solar cells, Ag back mirror improved short-circuit current density by $20 \%$ [65]. In the literature, the use of reflected light in DSSCs is reported rarely. However, some modifications such as reflecting counter electrode [66], photoanode including nanostructured light scattering layer [67] and combination of upconversion nanoparticles and light-reflecting silver particles were introduced [68], resulting in the enhancement of the electrical parameters of DSSCs.

\section{Conclusions}

The performance of dye-sensitized solar cells is influenced by numerous factors. This work addresses two aspects: proper selection of the sensitizing dye and application of a back reflector that allows harvesting the light transmitted through the semitransparent dye cell.

In the literature, great effort has been devoted to the development of new effective sensitizers, natural dyes among them. In the presented work, three organic metal-free dyes were chosen to serve as sensitizers in dye-sensitized solar cells: phenylfluorone, pyrocatechol violet and alizarin. The molecules of the investigated dyes possess an enediol group in their structure, which chelates with titanium and can ensure fast electron transfer 
from the excited sensitizer to the titanium dioxide nanoparticle layer that constitutes the photoactive coverage of illuminated electrodes in DSSCs. The prepared $\mathrm{TiO}_{2}$ layer showed porous morphology confirmed by scanning electron microscopy and high reflectance of $30-45 \%$ in the range of $400-600 \mathrm{~nm}$, favoring the harvesting of diffused light.

All the investigated dyes exhibited a significant broadening of absorption bands upon the adsorption on $\mathrm{TiO}_{2}$. The observed improvement of the light-harvesting properties together with the adequate distribution of the HOMO and LUMO positions qualified phenyl fluorine, pyrocatechol violet and alizarin for applications in DSSCs. The dye cells were fabricated, and their performance parameters were determined. Phenylfluorone was found as the best-performing sensitizer among the tested dyes, which was indicated by the beneficial values of chemical reactivity parameters. Phenylfluorone also presents the highest value of the absorbance at the absorption maximum and in consequence the highest value of the photocurrent. The observed differences in photocurrent obtained with the studied dyes are significant, which suggests that not only the light absorption but also the efficiency of electron injection differs among the dyes. However, internal resistances deteriorate the overall performance of the tested cells. Prospective improvement of the dye cells should include the reduction in resistance of metal contacts and better control of defects that contribute to leakage current.

In order to improve the efficiency, the reflective layer made of barium sulfate was implemented on the back side of the semitransparent cells. It was found that the application of back reflector is beneficial, and a significant improvement in the efficiency of the cells was observed. The achieved increase in the efficiency of the cells enriched with reflective layer was up to $60 \%$.

Although further optimization of dye cells is still necessary to gain better photovoltaic parameters, the application of the $\mathrm{BaSO}_{4}$ reflective layer is a very promising solution that can be introduced in all kinds of semitransparent cells.

Author Contributions: Conceptualization, A.Z.; methodology, E.K. and A.Z.; investigation, E.K. and A.Z.; writing, A.Z.; supervision, A.Z.; funding acquisition, A.Z. and E.K. All authors have read and agreed to the published version of the manuscript.

Funding: This research work was supported by statutory funds granted to the Faculty of Environmental Engineering, Lublin University of Technology, Poland.

Institutional Review Board Statement: Not applicable.

Informed Consent Statement: Not applicable.

Data Availability Statement: Not applicable.

Conflicts of Interest: The authors declare no conflict of interest.

\section{References}

1. Hagfeldt, A.; Grätzel, M. Molecular Photovoltaics. Acc. Chem. Res. 2000, 33, 269-277. [CrossRef] [PubMed]

2. Sánchez-de-Armas, R.; San-Miguel, M.; Oviedo, J.; Sanz, J.F. Direct vs. indirect mechanisms for electron injection in DSSC: Catechol and alizarin. Comput. Theor. Chem. 2011, 975, 99-105. [CrossRef]

3. Krawczyk, S.; Nawrocka, A.; Zdyb, A. Charge-transfer excited state in pyrene-1-carboxylic acids adsorbed on titanium dioxide nanoparticles. Spectrochim. Acta Part A Mol. Biomol. Spectrosc. 2018, 198, 19-26. [CrossRef]

4. Listorti, A.; O’Regan, B.; Durrant, J.R. Electron Transfer Dynamics in Dye-Sensitized Solar Cells. Chem. Mater. 2011, 23, 3381-3399. [CrossRef]

5. Chitpakdee, C.; Namuangruk, S.; Suttisintong, K.; Jungsuttiwong, S.; Keawin, T.; Sudyoadsuk, T.; Sirithip, K.; Promarak, V.; Kungwan, N. Effects of $\pi$-linker, anchoring group and capped carbazole at meso-substituted zinc-porphyrins on conversion efficiency of DSSCs. Dye. Pigment. 2015, 118, 64-75. [CrossRef]

6. Keawin, T.; Tarsang, R.; Sirithip, K.; Prachumrak, N.; Sudyoadsuk, T.; Namuangruk, S.; Roncali, J.; Kungwan, N.; Promarak, V.; Jungsuttiwong, S. Anchoring number-performance relationship of zinc-porphyrin sensitizers for dye-sensitized solar cells: A combined experimental and theoretical study. Dye. Pigment. 2017, 136, 697-706. [CrossRef]

7. Jie, J.; Xu, Q.; Yang, G.; Feng, Y.; Zhang, B. Porphyrin sensitizers involving a fluorine-substituted benzothiadiazole as auxiliary acceptor and thiophene as $\pi$ bridge for use in dye-sensitized solar cells (DSSCs). Dye. Pigment. 2020, 174, 107984. [CrossRef] 
8. Ambre, R.B.; Mane, S.B.; Chang, G.-F.; Hung, C.-H. Effects of Number and Position of Meta and Para Carboxyphenyl Groups of Zinc Porphyrins in Dye-Sensitized Solar Cells: Structure-Performance Relationship. ACS Appl. Mater. Interfaces 2015, 7, 1879-1891. [CrossRef] [PubMed]

9. Mathew, S.; Yella, A.; Gao, P.; Humphry-Baker, R.; Curchod, B.F.E.; Ashari-Astani, N.; Tavernelli, I.; Rothlisberger, U.; Nazeeruddin, K.; Grätzel, M. Dye-sensitized solar cells with 13\% efficiency achieved through the molecular engineering of porphyrin sensitizers. Nat. Chem. 2014, 6, 242-247. [CrossRef] [PubMed]

10. Narayanaswamy, K.; Swetha, T.; Kapil, G.; Pandey, S.S.; Hayase, S.; Singh, S.P. Simple Metal-Free Dyes Derived from Triphenylamine for DSSC: A Comparative Study of Two Different Anchoring Group. Electrochim. Acta 2015, 169, 256-263. [CrossRef]

11. Seo, K.D.; Song, H.M.; Lee, M.J.; Pastore, M.; Anselmi, C.; De Angelis, F.; Nazeeruddin, M.K.; Gräetzel, M.; Kim, H.K. Coumarin dyes containing low-band-gap chromophores for dye-sensitised solar cells. Dye. Pigment. 2011, 90, 304-310. [CrossRef]

12. Han, L.; Kang, R.; Zu, X.; Cui, Y.; Gao, J. Novel coumarin sensitizers based on 2-(thiophen-2-yl)thiazole $\pi$-bridge for dye-sensitized solar cells. Photochem. Photobiol. Sci. 2015, 14, 2046-2053. [CrossRef] [PubMed]

13. Naik, P.; Elmorsy, M.R.; Su, R.; Babu, D.D.; El-Shafei, A.; Adhikari, A.V. New carbazole based metal-free organic dyes with D- $\pi$-A- $\pi$-A architecture for DSSCs: Synthesis, theoretical and cell performance studies. Sol. Energy 2017, 153, 600-610. [CrossRef]

14. Naik, P.; Su, R.; Elmorsy, M.; El-Shafei, A.; Adhikari, A.V. Investigation of new carbazole based metal-free dyes as active photo-sensitizers/co-sensitizers for DSSCs. Dye. Pigment. 2018, 149, 177-187. [CrossRef]

15. Dai, P.-P.; Zhu, Y.-Z.; Liu, Q.-L.; Yan, Y.-Q.; Zheng, J.-Y. Novel indeno[1,2-b]indole-spirofluorene donor block for efficient sensitizers in dye-sensitized solar cells. Dye. Pigment. 2020, 175, 108099. [CrossRef]

16. Ghann, W.; Kang, H.; Emerson, E.; Oh, J.; Chavez-Gil, T.; Nesbitt, F.; Williams, R.; Uddin, J. Photophysical properties of near-IR cyanine dyes and their application as photosensitizers in dye sensitized solar cells. Inorg. Chim. Acta 2017, 467, 123-131. [CrossRef]

17. Ren, Y.; Sun, D.; Cao, Y.; Tsao, H.N.; Yuan, Y.; Zakeeruddin, S.M.; Wang, P.; Grätzel, M. A Stable Blue Photosensitizer for Color Palette of Dye-Sensitized Solar Cells Reaching 12.6\% Efficiency. J. Am. Chem. Soc. 2018, 140, 2405-2408. [CrossRef]

18. Kakiage, K.; Aoyama, Y.; Yano, T.; Oya, K.; Fujisawa, J.-I.; Hanaya, M. Highly-efficient dye-sensitized solar cells with collaborative sensitization by silyl-anchor and carboxy-anchor dyes. Chem. Commun. 2015, 51, 15894-15897. [CrossRef] [PubMed]

19. Richhariya, G.; Kumar, A.; Tekasakul, P.; Gupta, B. Natural dyes for dye sensitized solar cell: A review. Renew. Sustain. Energy Rev. 2017, 69, 705-718. [CrossRef]

20. Al-Alwani, M.A.; Ludin, N.A.; Mohamad, A.B.; Kadhum, A.A.H.; Mukhlus, A. Application of dyes extracted from Alternanthera dentata leaves and Musa acuminata bracts as natural sensitizers for dye-sensitized solar cells. Spectrochim. Acta Part A Mol. Biomol. Spectrosc. 2018, 192, 487-498. [CrossRef] [PubMed]

21. Al-Alwani, M.A.; Abu Hasan, H.; Al-Shorgani, N.K.N.; Al-Mashaan, A.B.S. Natural dye extracted from Areca catechu fruits as a new sensitiser for dye-sensitised solar cell fabrication: Optimisation using D-Optimal design. Mater. Chem. Phys. 2020, 240, 122204. [CrossRef]

22. Ferreira, F.; Babu, R.S.; Barros, A.; Raja, S.; da Conceição, L.; Mattoso, L. Photoelectric performance evaluation of DSSCs using the dye extracted from different color petals of Leucanthemum vulgare flowers as novel sensitizers. Spectrochim. Acta Part A Mol. Biomol. Spectrosc. 2020, 233, 118198. [CrossRef]

23. Keawwangchai, S.; Morakot, N.; Keawwangchai, T. Novel selective and sensitive optical chemosensor based on phenylfluorone derivative for detection of Ge(IV) ion in aqueous solution. Spectrochim. Acta Part A Mol. Biomol. Spectrosc. 2018, 202, 290-300. [CrossRef]

24. Ricciu, A.; Secco, F.; Venturini, M.; Garcia, B.; Leal, J.M. Kinetics and Equilibria of the Interaction of Indium(III) with Pyrocathecol Violet by Relaxation Spectrometry. J. Phys. Chem. A 2000, 104, 7036-7043. [CrossRef]

25. Sun, C.; Li, Y.; Han, J.; Cao, B.; Yin, H.; Shi, Y. Enhanced photoelectrical properties of alizarin-based natural dye via structure modulation. Sol. Energy 2019, 185, 315-323. [CrossRef]

26. Nawrocka, A.; Zdyb, A.; Krawczyk, S. Stark spectroscopy of charge-transfer transitions in catechol-sensitized $\mathrm{TiO}_{2}$ nanoparticles. Chem. Phys. Lett. 2009, 475, 272-276. [CrossRef]

27. Zdyb, A.; Krawczyk, S. Adsorption and electronic states of morin on $\mathrm{TiO}_{2}$ nanoparticles. Chem. Phys. 2014, 443, 61-66. [CrossRef]

28. Zdyb, A.; Krawczyk, S. Characterization of adsorption and electronic excited states of quercetin on titanium dioxide nanoparticles. Spectrochim. Acta Part A Mol. Biomol. Spectrosc. 2016, 157, 197-203. [CrossRef]

29. Pinto, A.L.; Cruz, L.; Gomes, V.; Cruz, H.; Calogero, G.; de Freitas, V.; Pina, F.; Parola, A.J.; Lima, J.C. Catechol versus carboxyl linkage impact on DSSC performance of synthetic pyranoflavylium salts. Dye. Pigment. 2019, 170, 107577. [CrossRef]

30. Mikhailov, M.; Yuryev, S.; Lapin, A.; Lovitskiy, A. The effects of heating on BaSO4 powders' diffuse reflectance spectra and radiation stability. Dye. Pigment. 2019, 163, 420-424. [CrossRef]

31. Ito, S.; Chen, P.; Comte, P.; Nazeeruddin, M.K.; Liska, P.; Péchy, P.; Grätzel, M. Fabrication of screen-printing pastes from TiO 2 powders for dye-sensitised solar cells. Prog. Photovolt. Res. Appl. 2007, 15, 603-612. [CrossRef]

32. Mosurkal, R.; He, J.-A.; Yang, K.; Samuelson, L.A.; Kumar, J. Organic photosensitizers with catechol groups for dye-sensitized photovoltaics. J. Photochem. Photobiol. A Chem. 2004, 168, 191-196. [CrossRef]

33. Xie, M.; Wang, J.; Xia, H.-Q.; Bai, F.-Q.; Jia, R.; Rim, J.-G.; Zhang, H.-X. Theoretical studies on the spectroscopic properties of porphyrin derivatives for dye-sensitized solar cell application. RSC Adv. 2015, 5, 33653-33665. [CrossRef]

34. Ruiz-Anchondo, T.; Flores-Holguín, N.; Glossman-Mitnik, D. Natural Carotenoids as Nanomaterial Precursors for Molecular Photovoltaics: A Computational DFT Study. Molecules 2010, 15, 4490-4510. [CrossRef] [PubMed] 
35. Zevallos, J.; Toro-Labbé, A. A Theoretical Analysis of the Kohn-Sham and Hartree-Fock Orbitals and Their Use in the Determination of Electronic Properties. J. Chil. Chem. Soc. 2003, 48, 39-47. [CrossRef]

36. Parr, R.G.; Szentpály, L.V.; Liu, S. Electrophilicity Index. J. Am. Chem. Soc. 1999, 121, 1922-1924. [CrossRef]

37. Parthasarathi, R.; Padmanabhan, J.; Elango, M.; Subramanian, V.; Chattaraj, P. Intermolecular reactivity through the generalized philicity concept. Chem. Phys. Lett. 2004, 394, 225-230. [CrossRef]

38. Grätzel, M. Recent Advances in Sensitized Mesoscopic Solar Cells. Acc. Chem. Res. 2009, 42, 1788-1798. [CrossRef]

39. Krawczak, E.; Zdyb, A. The Effect of Electrode Immersion Time and Ageing on N719 Dye-Sensitized Solar Cells Performance. J. Ecol. Eng. 2020, 21, 53-60. [CrossRef]

40. Wang, W.; Yuan, H.; Xie, J.; Xu, D.; Chen, X.; He, Y.; Zhang, T.; Chen, Z.; Zhang, Y.; Shen, H. Enhanced efficiency of large-area dye-sensitized solar cells by light-scattering effect using multilayer $\mathrm{TiO}_{2}$ photoanodes. Mater. Res. Bull. 2018, 100, 434-439. [CrossRef]

41. Huang, W.-Y.; Hsieh, T.-L. Dyes Amount and Light Scattering Influence on the Photocurrent Enhancement of Titanium Dioxide Hierarchically Structured Photoanodes for Dye-Sensitized Solar Cells. Coatings 2020, 10, 13. [CrossRef]

42. Gladkova, O.L.; Panarin, A.; Khodasevich, I.A.; Terekhov, S.N. Surface-enhanced Raman spectra of a complex of antimony with phenylfluorone and their interpretation. Opt. Spectrosc. 2012, 112, 489-496. [CrossRef]

43. de Sousa, J.M.; Couto, M.T.; Cassella, R.J. Polyurethane foam functionalized with phenylfluorone for online preconcentration and determination of copper and cadmium in water samples by flame atomic absorption spectrometry. Microchem. J. 2018, 138, 92-97. [CrossRef]

44. Balaji, T.; Matsunaga, H. Naked-eye detection of fluoride using Zr(IV)-EDTA complex and pyrocatechol violet. Anal. Sci. 2005, 21, 973-977. [CrossRef]

45. Lee, C.; Ko, Y.-J.; Lee, S.-Y. A pyrocatechol violet-titanium alkoxide complex for HF sensing: Study on the complex structure and application. Dye. Pigment. 2016, 127, 133-141. [CrossRef]

46. Gomez, T.; Hermann, G.; Zarate, X.; Pérez-Torres, J.F.; Tremblay, J.C. Imaging the Ultrafast Photoelectron Transfer Process in Alizarin- $-\mathrm{TiO}_{2}$. Molecules 2015, 20, 13830-13853. [CrossRef] [PubMed]

47. Galappaththi, K.; Ekanayake, P.; Petra, M.I. A rational design of high efficient and low-cost dye sensitizer with exceptional absorptions: Computational study of cyanidin based organic sensitizer. Sol. Energy 2018, 161, 83-89. [CrossRef]

48. Islam, A.; Sugihara, H.; Arakawa, H. Molecular design of ruthenium(II) polypyridyl photosensitizers for efficient nanocrystalline $\mathrm{TiO}_{2}$ solar cells. J. Photochem. Photobiol. A Chem. 2003, 158, 131-138. [CrossRef]

49. Feng, S.; Li, Q.-S.; Niehaus, T.A.; Li, Z.-S. Effects of different electron donating groups on dye regeneration and aggregation in phenothiazine-based dye-sensitized solar cells. Org. Electron. 2017, 42, 234-243. [CrossRef]

50. Macyk, W.; Szaciłowski, K.; Stochel, G.; Buchalska, M.; Kuncewicz, J.; Łabuz, P. Titanium(IV) complexes as direct TiO 2 photosensitizers. Coord. Chem. Rev. 2010, 254, 2687-2701. [CrossRef]

51. Dayan, S.; Kayaci, N.; Özpozan, N.K. Improved performance with molecular design of Ruthenium(II) complexes bearing diamine-based bidentate ligands as sensitizer for dye-sensitized solar cells (DSSC). J. Mol. Struct. 2020, 1209, 127920. [CrossRef]

52. Zhang, C.; Xie, Y.; Bai, T.; Hu, J.; Wang, J. Cooperation of multifunction composite structures and fluorescein for photovoltaic performance-enhanced ZnO-based dye-sensitized solar cells. J. Power Sources 2015, 297, 16-22. [CrossRef]

53. Funabiki, K.; Sugiyama, N.; Iida, H.; Jin, J.-Y.; Yoshida, T.; Kato, Y.; Minoura, H.; Matsui, M. Ring-fluorinated fluoresceins as an organic photosensitizer for dye-sensitized solar cells using nanocrystalline zinc oxide. J. Fluor. Chem. 2006, 127, $257-262$. [CrossRef]

54. Sarker, A.K.; Kang, M.G.; Hong, J.-D. A near-infrared dye for dye-sensitized solar cell: Catecholate-functionalized zinc phthalocyanine. Dye. Pigment. 2012, 92, 1160-1165. [CrossRef]

55. Manmeeta, S.D.; Saxena, D.; Sharma, G.D.; Roy, M.S. Improved performance of oxidized Alizarin based Quasi solid state Dye Sensitized solar cell by Surface Treatment. Res. J. Chem. Sci. 2012, 2, 61-71.

56. Ramachandran, A.; Sreekala, C.O.; Sreelatha, K.S.; Jinchu, I. Photovoltaic studies of Dye Sensitized Solar cells Fabricated from Microwave Exposed Photo anodes. IOP Conf. Ser. Mater. Sci. Eng. 2018, 310, 012151. [CrossRef]

57. Hamadanian, M.; Safaei-Ghomi, J.; Hosseinpour, M.; Masoomi, R.; Jabbari, V. Uses of new natural dye photosensitizers in fabrication of high potential dye-sensitized solar cells (DSSCs). Mater. Sci. Semicond. Process. 2014, 27, 733-739. [CrossRef]

58. DeSilva, L.A.; Pitigala, P.K.D.D.P.; Gaquere-Parker, A.; Landry, R.; Hasbun, J.E.; Martin, V.; Bandara, T.M.W.J.; Perera, A.G.U. Broad absorption natural dye (Mondo-Grass berry) for dye sensitized solar cell. J. Mater. Sci. Mater. Electron. 2017, 28, 7724-7729. [CrossRef]

59. Omar, A.; Ali, M.S.; Rahim, N.A. Electron transport properties analysis of titanium dioxide dye-sensitized solar cells (TiO ${ }_{2}$-DSSCs) based natural dyes using electrochemical impedance spectroscopy concept: A review. Sol. Energy 2020, 207, 1088-1121. [CrossRef]

60. Błaszczyk, A.; Joachimiak-Lechman, K.; Sady, S.; Tański, T.; Szindler, M.; Drygała, A. Environmental performance of dye-sensitized solar cells based on natural dyes. Sol. Energy 2021, 215, 346-355. [CrossRef]

61. Guermit, N.; Remache, L.; Lorrain, N.; Guendouz, M.; Charrier, J. Theoretical and experimental study of Fermi Bragg reflector as application for thin silicon solar cells. Opt. Mater. 2020, 100, 109615. [CrossRef]

62. Ren, R.; Zhong, Z. Enhanced light absorption of silicon solar cells with dielectric nanostructured back reflector. Opt. Commun. 2018, 417, 110-114. [CrossRef] 
63. Wang, M.; Ye, X.; Wan, X.; Liu, Y.; Xie, X. Brilliant white polystyrene microsphere film as a diffuse back reflector for solar cells. Mater. Lett. 2015, 148, 122-125. [CrossRef]

64. Berger, O.; Inns, D.; Aberle, A.G. Commercial white paint as back surface reflector for thin-film solar cells. Sol. Energy Mater. Sol. Cells 2007, 91, 1215-1221. [CrossRef]

65. Gouillart, L.; Cattoni, A.; Goffard, J.; Donsanti, F.; Patriarche, G.; Jubault, M.; Naghavi, N.; Collin, S. Development of reflective back contacts for high-efficiency ultrathin $\mathrm{Cu}(\mathrm{In}, \mathrm{Ga}) \mathrm{Se}_{2}$ solar cells. Thin Solid Film. 2019, 672, 1-6. [CrossRef]

66. S., I.R.; Xu, X.; Yang, W.; Yang, F.; Hou, L.; Li, Y. Highly active and reflective MoS2 counter electrode for enhancement of photovoltaic efficiency of dye sensitized solar cells. Electrochim. Acta 2016, 212, 614-620. [CrossRef]

67. Mohammadian-Sarcheshmeh, H.; Arazi, R.; Mazloum-Ardakani, M. Application of bifunctional photoanode materials in DSSCs: A review. Renew. Sustain. Energy Rev. 2020, 134, 110249. [CrossRef]

68. Ramasamy, P.; Kim, J. Combined plasmonic and upconversion rear reflectors for efficient dye-sensitized solar cells. Chem. Commun. 2014, 50, 879-881. [CrossRef] [PubMed] 